\title{
Role of Divalent Cations in the Action of Polymyxin B and EDTA on Pseudomonas aeruginosa
}

\author{
By M. R. W. BROWN AND J. MELLING \\ Pharmaceutical Microbiology Group, School of Pharmacy, Bath \\ University of Technology, Bath, Somerset, BA2 $7 A Y$
}

(Accepted for publication 30 August 1969)

\section{SUMMARY}

Pseudomonas aeruginosa grown under conditions of Mg-depletion in batch eulture in simple salts medium lost sensitivity to polymyxin B, causing lysis, release of $260 \mathrm{~nm}$. absorbing materials and loss of viability. The patterns of lysis and leakage produced by polymyxin were similar with regard to the effect of growth in different $\mathrm{Mg}$ concentrations and the inhibitory effect of high polymyxin concentrations. The rates of lysis and leakage for any one suspension were similar. There was decreased polymyxin uptake by insensitive bacteria. Addition of $\mathrm{Mg}$ or one of several cations restored sensitivity both to polymyxin and to EDTA to varying degrees, but only after several cell divisions had occurred. A close similarity was observed between the effects of Mg-depletion on sensitivity to EDTA and to polymyxin; a relationship between their mechanisms of action is suggested. It is proposed that cations are essential for the synthesis of sensitive components of the envelope and may themselves be involved in the structure of the component.

\section{INTRODUCTION}

Growth of Pseudomonas aeruginosa in Mg-depleted cultures resulted in loss of sensitivity to the antibacterial action of ethylenediaminetetra-acetic acid (EDTA) (Brown \& Melling, I969). This phenomenon has now been further investigated and the effect of polymyxin B sulphate on $P$. aeruginosa grown in media with various $\mathrm{Mg}$ concentrations examined. Polymyxin was chosen since it was reported to be active against this organism (Haas \& Sevag, 1953), and Newton (1954) showed its action to be antagonized by divalent cations. Polymyxin was also of interest since, unlike EDTA, it has been reported not to act by a chelation mechanism (Newton, I953a). Other divalent cations were examined for ability to substitute for $\mathrm{Mg}$ in its role concerned with the resistance of $P$. aeruginosa, particularly in view of the finding of Eagon, Simmons \& Carson (1965) who identified $\mathrm{Mg}, \mathrm{Ca}$ and $\mathrm{Zn}$ in cell walls of $P$. aeruginosa.

\section{METHODS}

Organism. Pseudomonas aeruginosa NCTC 6750 was used throughout this work.

Chemicals. All chemicals used were of Analytical Reagent grade (AnalarR).

Cleaning procedures. All glassware was treated with chromic+sulphuric acid mixture, washed with tap water and finally with glass-distilled water.

Culture methods. The organism was maintained in a liquid medium consisting of: $0.00 \mathrm{I}$ M-D $(+)$ glucose, $0.0 \mathrm{I} \mathrm{M}-\left(\mathrm{NH}_{4}\right)_{2} \mathrm{HPO}_{4}, \quad 0.0 \mathrm{I} \mathrm{M}-\left(\mathrm{NH}_{4}\right)_{2} \mathrm{SO}_{4}, \quad 0.0005 \mathrm{M}-\mathrm{NaCl}$, $0.0005 \mathrm{M}-\mathrm{KCl}$ dissolved in glass-distilled water. In the following experiments bacteria 
were grown in media identical to the above, but containing different concentrations of the divalent cations. Samples (500 ml.) of bacterial suspensions were grown in 21. flasks in a Mickle shaker bath (The Mickle Laboratory Engineering Co., Gomshall, Surrey) at $37.5^{\circ}$. Cultures with the lower concentrations of $\mathrm{Mg}$ gradually entered a stationary phase due to $\mathrm{Mg}$-depletion. Growth eventually ceased owing to depletion of glucose at an extinction of about 0.180 measured at $470 \mathrm{~nm}$. with a Unicam SP600 spectrophotometer. This extinction corresponded to a colony count of about $3.5 \times 10^{8}$ bacteria/ml. When no increase in $E_{470}$ had been observed over a period of $\mathrm{I} \mathrm{hr}$, samples were taken and treated with polymyxin or EDTA.

Treatment of bacteria with polymyxin or EDTA. Samples of culture $(93 \mathrm{ml}$.) at $37.5^{\circ}$ were added to $7 \mathrm{ml}$. of EDTA or polymyxin solutions of various concentrations contained in $250 \mathrm{ml}$. flasks and maintained at the same temperature. The mixture remained constant at $\mathrm{pH} 7 \cdot 2$.

Measurement of lysis and colony counts. These were made as described previously (Brown \& Melling, 1969).

Measurement of $260 \mathrm{~nm}$-absorbing substances released from bacteria. Estimates of $260 \mathrm{~nm}$.-absorbing substances released from bacteria were made by the technique of Brown, Farwell \& Rosenbluth (I969). This involved removal of bacteria by membrane filtration and measurement of the extinction at $260 \mathrm{~nm}$. of the filtrate with a Unicam SP 500 spectrophotometer.

\section{RESULTS}

\section{Effect of $\mathrm{Mg}$-depletion on lysis by polymyxin}

The $E_{470}$ of cultures grown in a range of $\mathrm{Mg}$ concentrations was measured at intervals after treatment with various polymyxin concentrations. Figure I shows the typical effects of polymyxin treatment on bacteria grown in I $\mu \mathrm{g} . / \mathrm{ml}$. (excess) and $0.05 \mu \mathrm{g} . \mathrm{Mg} / \mathrm{ml}$. (depleted), respectively. Little change in $E_{470}$ of the culture containing $0.05 \mu \mathrm{g}$. Mg $/ \mathrm{ml}$. occurred compared to the culture containing I $\mu \mathrm{g} . / \mathrm{ml}$. The changes in $E_{470}$ observed in the latter culture indicated that lysis of bacteria occurred after treatment at the lower polymyxin concentrations, and that the rate of lysis increased as the polymyxin concentration was increased up to 32 units $/ \mathrm{ml}$. Further increases in polymyxin concentration resulted in decreased lysis; treatment with 256 units $/ \mathrm{ml}$. caused a rapid initial increase in $E_{470}$.

The activity of any one concentration of polymyxin in causing lysis was taken to be the decrease in $E_{470}$ after I80 min. treatment with polymyxin compared to the $E_{470}$ at zero time. Figure 2 shows the activity of several polymyxin concentrations in causing lysis of bacteria grown in different $\mathrm{Mg}$ concentrations. The rate of lysis reached a peak at a particular polymyxin concentration. There appears to be some correlation between the polymyxin concentration at which the peak occurred and the $\mathrm{Mg}$ concentration in the growth medium, the peak being reached at a lower polymyxin concentration as the $\mathrm{Mg}$ concentration increased. The culture containing $4 \mu \mathrm{g} . \mathrm{Mg} / \mathrm{ml}$. was an exception, possibly due to antagonism of polymyxin by $\mathrm{Mg}$ (Newton, 1954).

Figure 3 shows the effect of growth in different $\mathrm{Mg}$ concentration on the maximum rate of lysis resulting from polymyxin treatment and it can be seen that the greatest change occurred at $\mathrm{Mg}$ concentration below $0.5 \mu \mathrm{g} . / \mathrm{ml}$. An almost identical pattern of sensitivity to lysis with Mg-depletion has been shown with EDTA (Brown \& Melling 1969). 

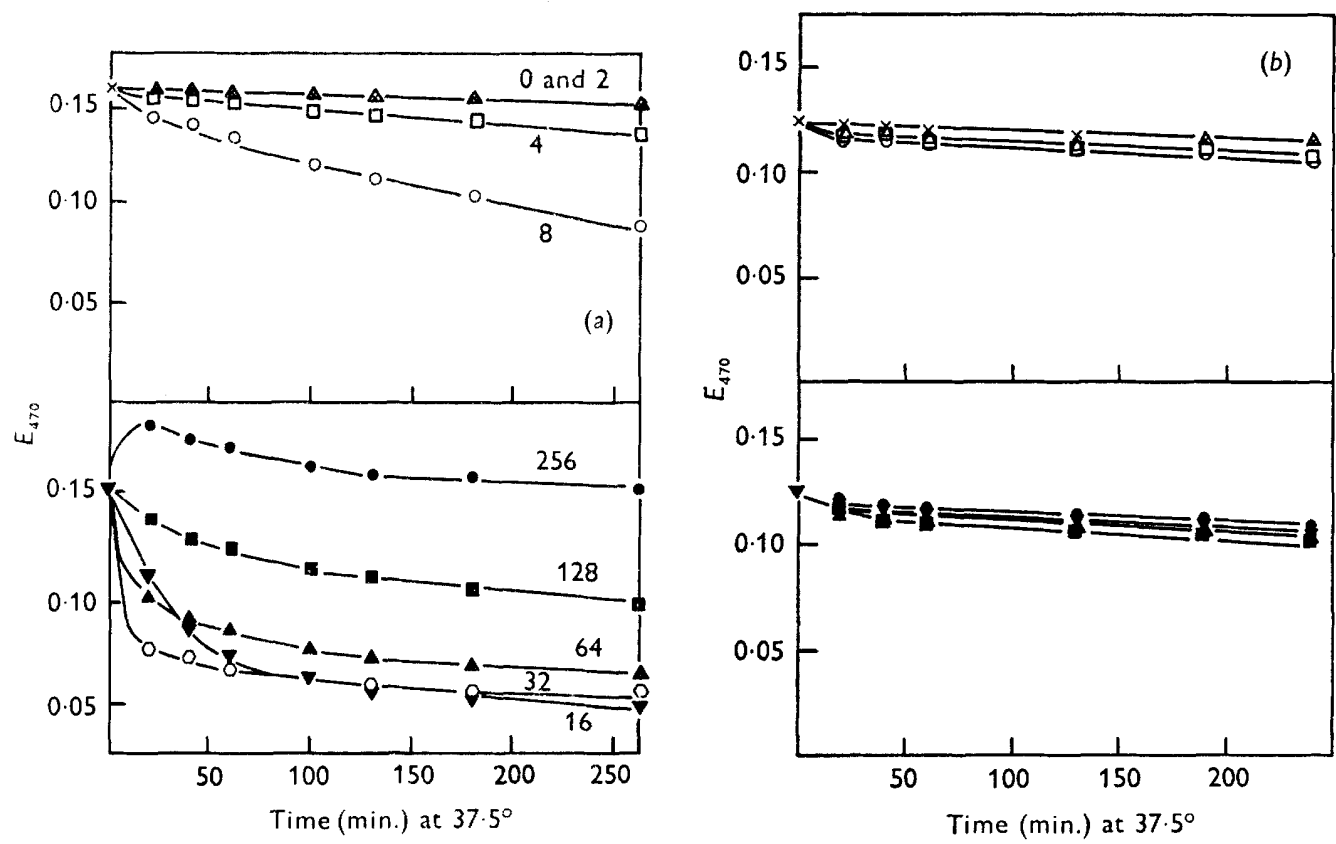

Fig. I. Effect of polymyxin concentration on lysis of Pseudomonas aeruginosa grown in medium with: (a) I $\mu \mathrm{g}$. $\mathrm{Mg} / \mathrm{ml}$; ; bacteria not $\mathrm{Mg}$-depleted. (b) $0.05 \mu \mathrm{g}$. $\mathrm{Mg} / \mathrm{ml}$; bacteria Mg-depleted. Polymyxin concentrations (units $/ \mathrm{ml}$.) were: $\times$, zero, $\Delta, 2 ; \square, 4 ; O, 8$; $\nabla, 16 ; 0,32 ; \Delta, 64 ; \mathbf{Q}, 128 ; 0,256$.
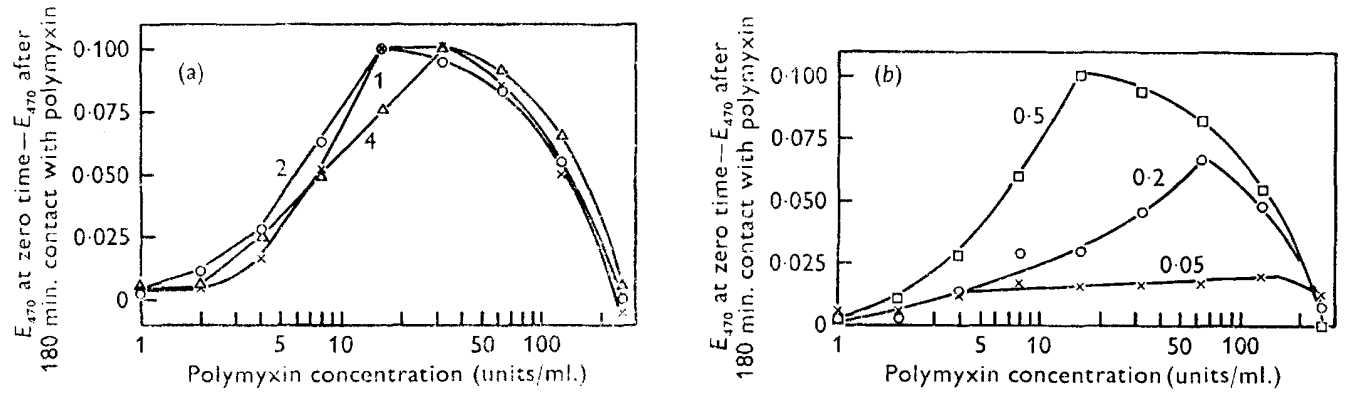

Fig. 2. Effect of polymyxin concentration on rate of lysis of Pseudomonas aeruginosa grown in media containing different $\mathrm{Mg}$ concentrations. $\mathrm{Mg}$ concentrations $(\mu \mathrm{g}$. $/ \mathrm{ml}$.) were: $(a) \times$, $\mathrm{x} ; \mathrm{O}, 2 ; \Delta, 4 ;(b) \times, 0.05 ; 0,0.2 ; \square, 0.5$.

\section{Effect of $M g$-depletion on release of $260 \mathrm{~nm}$.-absorbing substances by polymyxin}

Release of material absorbing at $260 \mathrm{~nm}$. from Pseudomonas aeruginosa treated with polymyxin followed a similar pattern to that observed for lysis by this antibiotic. Typical results are shown in Fig. 4 for bacteria grown in I $\mu \mathrm{g}$. and $0.05 \mu \mathrm{g}$. Mg/ml., respectively. Clearly little loss of $250 \mathrm{~nm}$.-absorbing material occurred from bacteria grown in the lower magnesium concentration. Figure 5 shows the activity of several polymyxin concentrations in causing leakage from bacteria grown in different $\mathbf{M g}$ concentrations. As the polymyxin concentration increased the rate of leakage also 
increased to a maximum and then was decreased at high concentration. Examination of the effect of growth in different $\mathrm{Mg}$ concentrations on leakage (Fig. 6) showed that the maximum rate of leakage increased as the $\mathrm{Mg}$ concentration in the growth medium increased from 0.05 to $0.5 \mu \mathrm{g} . / \mathrm{ml}$.

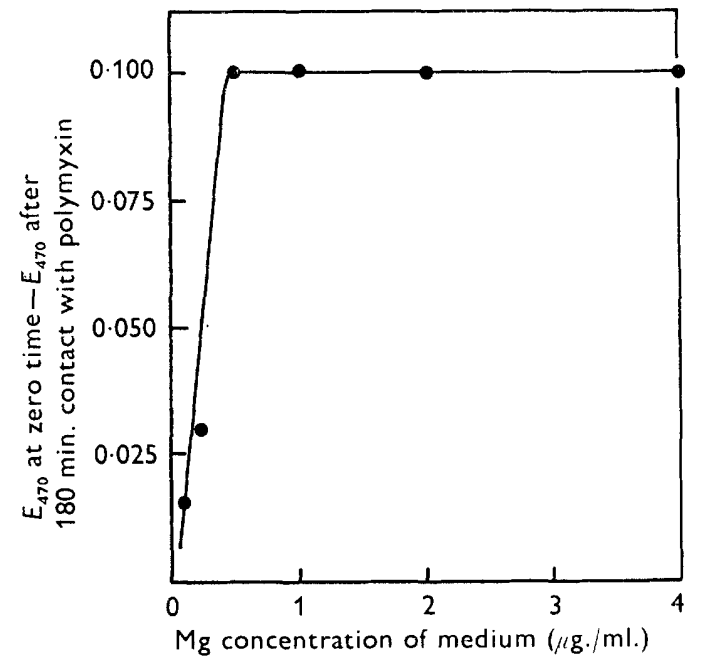

Fig. 3. Maximum lysis $\left(E_{470}\right)$ by polymyxin (units/ml.) of Pseudomonas aeruginosa grown in media containing graded $\mathrm{Mg}$ concentrations.
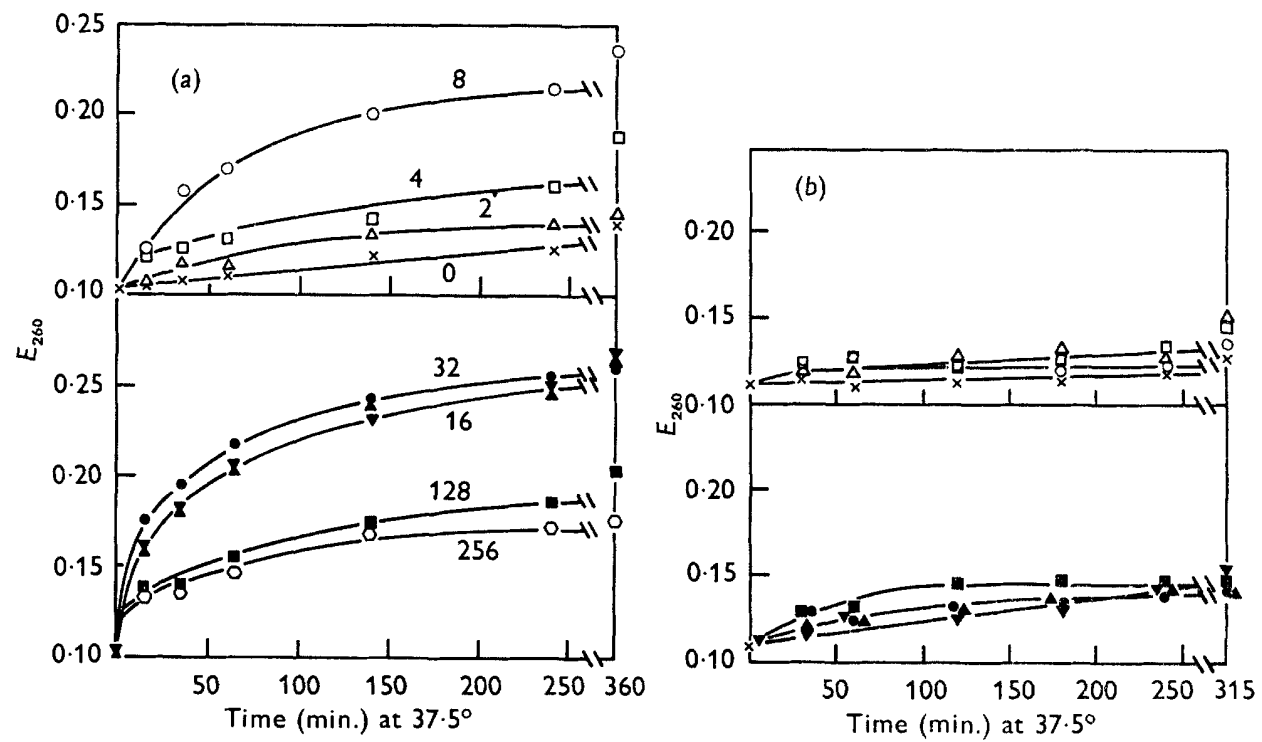

Fig. 4. Effect of polymyxin concentration on leakage $\left(E_{280}\right)$ from Pseudomonas aeruginosa grown in medium with: $(a)$ I $\mu \mathrm{g}$. $\mathrm{Mg} / \mathrm{ml}$; ; bacteria not Mg-depleted. Polymyxin concentrations (units/ml.) were: $\times$, zero; $\triangle, 2 ; \square, 4 ; \bigcirc, 8 ; \nabla, 16 ; \bullet, 32 ; \Delta, 64 ; \square, 128 ; 0,256$. (b) $0.05 \mu \mathrm{g}$. $\mathrm{Mg} / \mathrm{ml}$.; bacteria Mg-depleted. Polymyxin concentrations were: $\times$, zero; 0,$2 ; \square, 4 ; \triangle, 16 ; \nabla, 32 ; \bigcirc 64 ; \Delta, 128 ; \square, 256$. 


\section{Effect of Mg-depletion on release of $260 \mathrm{~nm}$.- absorbing substances by EDTA}

In a previous paper (Brown \& Melling, 1969) dealing with the effect of EDTA on Mg-depleted Pseudomonas aeruginosa, the effect of EDTA on release of $260 \mathrm{~nm}$.absorbing material was not reported. This was due to an anomaly in the measurement of $E_{260}$ in the presence of EDTA, which resulted in higher values than expected from the sum of the components. This anomaly was resolved for present purposes by making a comparison between the observed $E_{260}$ values of solutions containing graded amounts
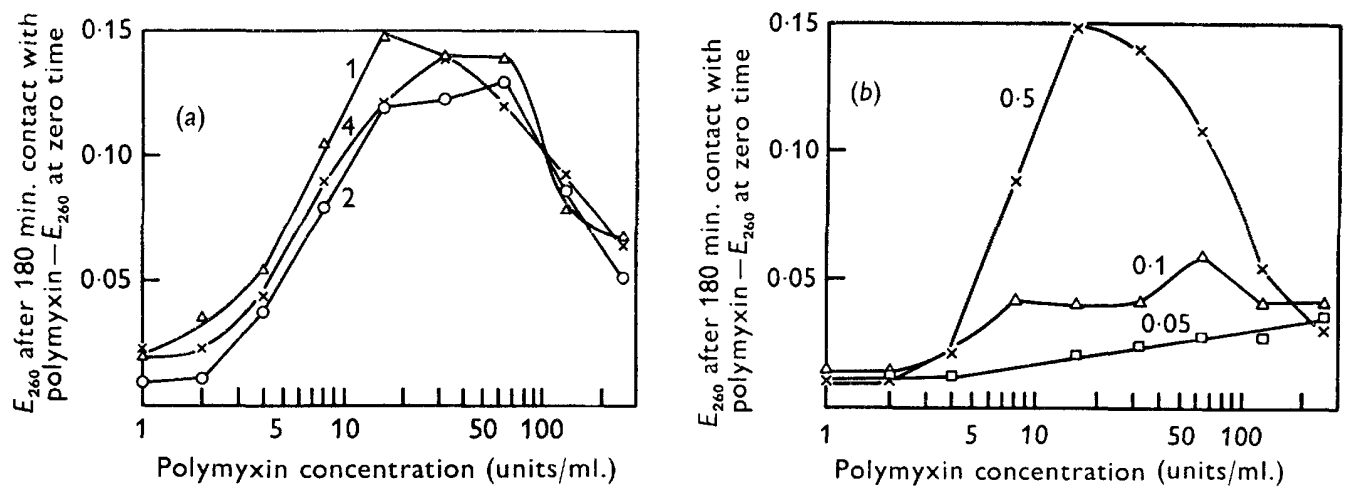

Fig. 5. Activity of various polymyxin concentrations in causing leakage $\left(E_{280}\right)$ from $P_{\text {seudo- }}$ monas aeruginosa grown in media containing different $\mathrm{Mg}$ concentrations. $\mathrm{Mg}$ concentrations $(\mu \mathrm{g} . / \mathrm{ml}$.) were: (a) $\Delta, \mathrm{I} ; 0,2 ; \times, 4 ;(b) \square, 0.05 ; \triangle, 0.1 ; \times, 0.5$.

of culture filtrate +EDTA, and the expected $E_{260}$ assuming the extinctions of EDTA and filtrate to be additive (Melling, 1968). For example, the $E_{260}$ of a solution containing $1000 \mu \mathrm{g}$. EDTA $/ \mathrm{ml}$. was 0.007, and the $E_{260}$ of culture filtrate was 0.138. Thus, the expected $E_{260}$ of the mixture was 0.I45; but the observed value was 0.163. However, the $E_{260}$ of EDTA and $260 \mathrm{~nm}$.-absorbing material released from bacteria washed free from the growth medium was additive. It seems probable that EDTA forms a complex with some metabolic product of $P$. aeruginosa and that this complex absorbs more strongly at $260 \mathrm{~nm}$. than do its components. An extinction greater than additive was not observed with cell exudate from washed bacteria; this suggests that the complex was formed with an extracellular product of metabolism rather than the characteristic leakage products.

Release of $260 \mathrm{~nm}$.-absorbing substances from Pseudomonas aeruginosa grown in different $\mathrm{Mg}$ concentrations and treated with EDTA was estimated. Typical results are shown in Fig. 7. The zero-time readings were obtained by adding the particular EDTA concentration to a sample of the culture filtrate. Thus, increases in $E_{260}$ above the zero reading were solely a result of cell leakage since the non-additive increase in absorption did not occur with leakage products. Inspection of Fig. 7 shows that bacteria grown in the lower $\mathrm{Mg}$ concentration lost little $260 \mathrm{~nm}$.-absorbing material as compared with those grown in the higher concentration.

The activity of any EDTA concentration in causing leakage was measured as the increase in $E_{260}$ of the culture filtrate after $180 \mathrm{~min}$. treatment with EDTA. Figure 8 shows the activity of EDTA in causing leakage from Pseudomonas aeruginosa grown 
in different $\mathrm{Mg}$ concentrations. The pattern of leakage was very similar to that for lysis caused by EDTA (Brown \& Melling, 1969). The EDTA concentration required to produce maximum lysis was greater the higher the $\mathrm{Mg}$ concentration; the maximum rate of lysis increased as the $\mathrm{Mg}$ concentration in the growth medium increased.

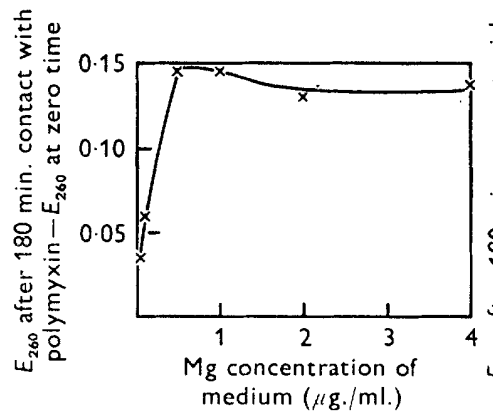

Fig. 6

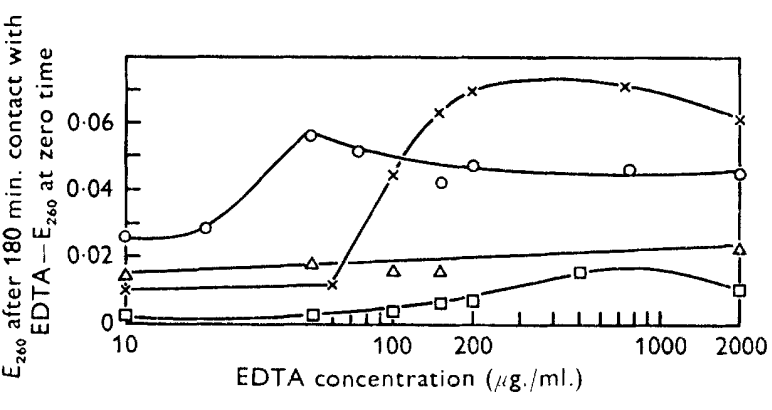

Fig. 8
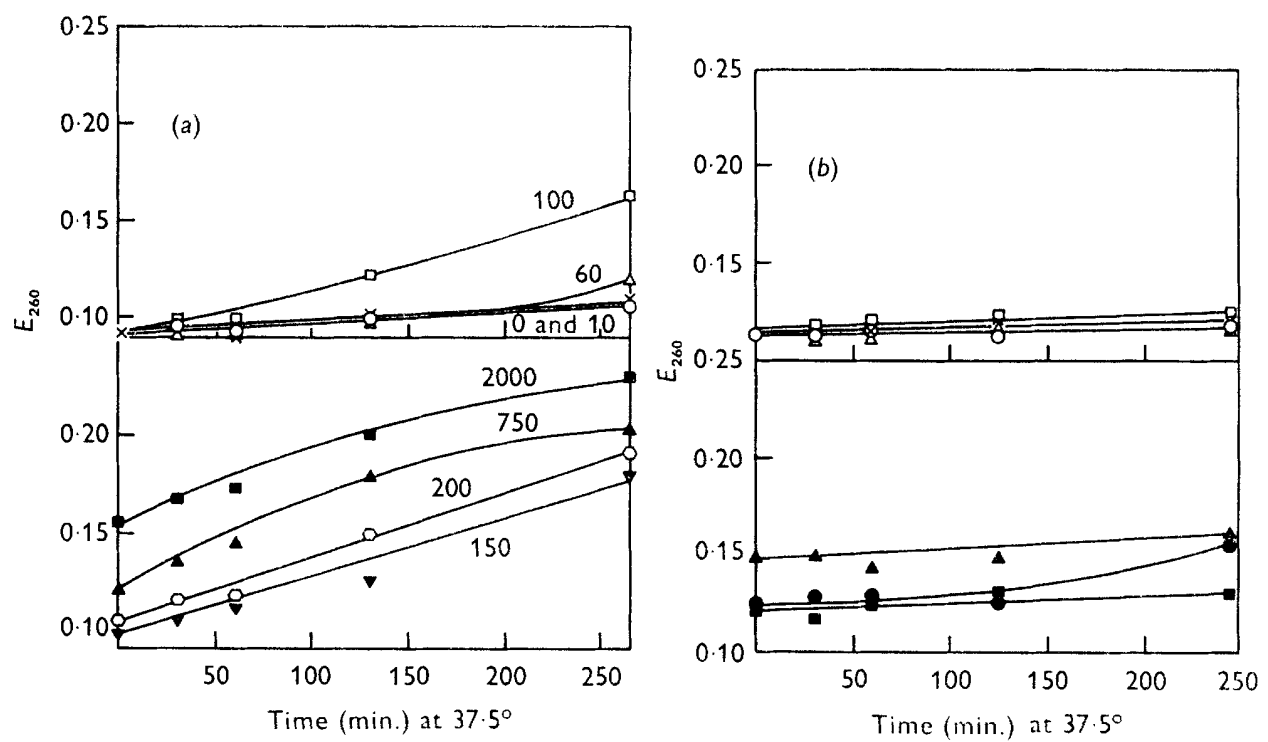

Fig. 7

Fig. 6. Maximum leakage $\left(E_{260}\right)$ caused by polymyxin from $P$ seudomonas aeruginosa grown in media containing graded $\mathrm{Mg}$ concentrations.

Fig. 7. Effect of EDTA concentration on leakage $\left(E_{260}\right)$ from Pseudomonas aeruginosa grown in medium with: (a) $4 \mu \mathrm{g}$. Mg/ml.; bacteria not Mg-depleted. EDTA concentrations ( $\mu \mathrm{g} . / \mathrm{ml}$.) were: $x$, zero; $O$, I0; $\triangle, 60 ; \square, 100 ; \nabla, 150 ; 0,200 ; \Delta, 750 ; \square, 2000 .(b)$ $0.05 \mu \mathrm{g} . \mathrm{Mg} / \mathrm{ml}$.; bacteria Mg-depleted. EDTA concentrations $(\mu \mathrm{g} . / \mathrm{ml}):. \bigcirc$, zero; $\triangle, 50$; $\times$, I00; $\square$, I $50 ; \boldsymbol{\square}, 200 ; \bullet, 500 ; \mathbf{A}, 750$.

Fig. 8. Activity of various EDTA concentrations in causing leakage $\left(E_{280}\right)$ from Pseudomunas aeruginosa grown in media containing graded $\mathrm{Mg}$ concentrations. $\mathrm{Mg}$ concentrations $(\mu \mathrm{g} . / \mathrm{ml}):. \square, 0.05 ; \triangle, 0.1 ; 0,0.5 ; \times, 4$. 


\section{Effect of polymyxin on colony count of $\mathrm{Mg}$-depleted bacteria}

Two polymyxin concentrations were tested for their effect upon the viability of Pseudomonas aeruginosa grown in I and $0.05 \mu \mathrm{g} . \mathrm{Mg} / \mathrm{ml}$. Dilutions for counting were made in lecithin broth. These two $\mathrm{Mg}$ concentrations were selected since they resulted in the production of sensitive and resistant bacteria, respectively, when lysis and leakage were the parameters being measured. The results are shown in Fig. 9a. Unlike the effects on lysis and leakage 256 units $/ \mathrm{ml}$. polymyxin caused a greater loss of viability compared to 16 units $/ \mathrm{ml}$. Figure $9 b$ shows the effect of growth in different $\mathrm{Mg}$ concentrations on the decrease in colony count after $180 \mathrm{~min}$. resulting from treatment with I6 units polymyxin/ml. Again, bacteria grown in the lower $\mathrm{Mg}$ concentrations showed the greater resistance to polymyxin.
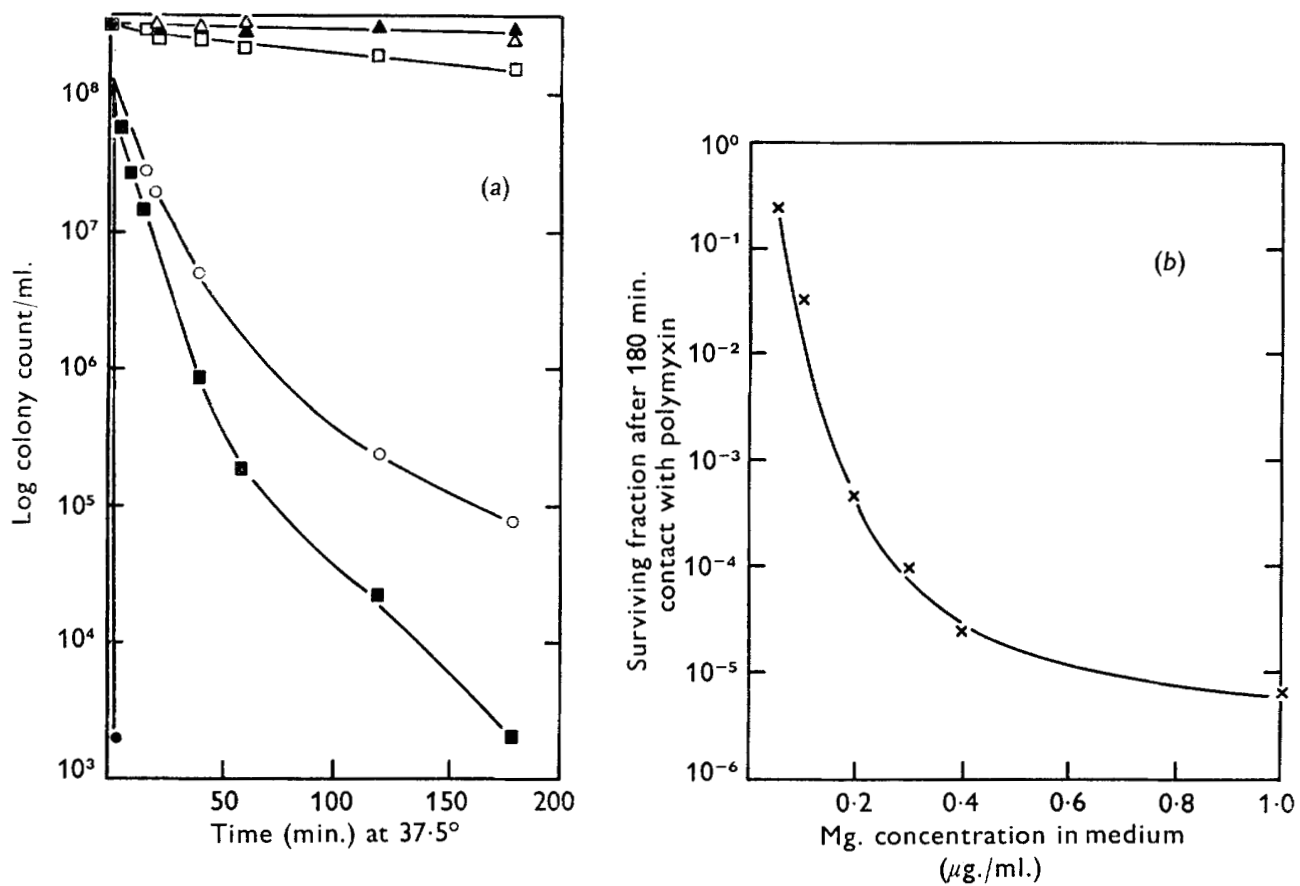

Fig. 9. Effect of treatment with polymyxin on the viability of Pseudomonas aeruginosa grown in media containing different $\mathrm{Mg}$ concentrations: $(a) \mathrm{Mg}$ concentrations $(\mu \mathrm{g} . / \mathrm{ml}$.) were: open symbols, 0.05 (Mg-depleted); closed symbols, I (Mg-plentiful). Polymyxin concentrations (units $/ \mathrm{ml}$.) were: $\triangle, \Delta$, zero; $\square, \boldsymbol{\square}, 16 ; \bigcirc, 0,256 .(\mathrm{b})$ Polymyxin concentration was 16 units $/ \mathrm{ml}$.

\section{Effect of adding $M g$ and other divalent cations to Mg-depleted cultures}

Bacteria were grown in a low $\mathrm{Mg}$ concentration $(0.05 \mu \mathrm{g} . / \mathrm{ml}$.) and the concentration increased to I $\mu \mathrm{g}$. $/ \mathrm{ml}$. at various times before growth ceased because of glucose depletion. Samples of the ensuing stationary phase culture were taken and treated with I 6 units polymyxin $/ \mathrm{ml}$. or $375 \mu \mathrm{g}$. EDTA $/ \mathrm{ml}$. Since release of $260 \mathrm{~nm}$.-absorbing material and loss of viability caused by the two agents were reflected by lysis of bacteria, the change in $E_{470}$ of cultures was the parameter chosen to examine this. The 
data in Table $\mathrm{I}$ indicate that the longer the bacteria had grown in a high $\mathrm{Mg}$ concentration the more susceptible they became to the two agents. The addition of $\mathrm{Mg}$ to cultures whose growth rate was decreased because of $\mathrm{Mg}$-depletion caused an immediate increase in growth rate; subsequent measurements showed no immediate change, but rather a very gradual one, in sensitivity to polymyxin or EDTA.

Addition of I $\mu \mathrm{g} . \mathrm{Mg} / \mathrm{ml}$. after cell division had ceased because of glucose depletion did not render the bacteria sensitive to EDTA or polymyxin even when $6 \mathrm{hr}$ had elapsed before treatment with these agents began. Thus cell division in a high $\mathrm{Mg}$ concentration was required to render the organism sensitive to these agents.

Table I. Effect on sensitivity to lysis by polymyxin or EDTA of adding $\mathrm{I} \mu \mathrm{g} . \mathrm{Mg} / \mathrm{ml}$. to cultures of Pseudomonas aeruginosa containing $0.05 \mu \mathrm{g} . \mathrm{Mg} / \mathrm{ml}$., at intervals before the cultures entered stationary phase

\begin{tabular}{ccc} 
Time (hr) before & $\begin{array}{c}\text { Polymyxin } \\
\text { (I6 units } / \mathrm{ml} .)\end{array}$ & $\begin{array}{c}\text { EDTA } \\
\text { stationary phase }\end{array}$ \\
\cline { 2 - 3 } 0 & 0.010 & 0.009 \\
0.75 & 0.019 & 0.016 \\
2.0 & 0.050 & 0.020 \\
4.5 & 0.095 & 0.057 \\
5.5 & 0.114 & 0.070 \\
25.0 & 0.103 & 0.092 \\
Control: no extra Mg & 0.018 & 0.011
\end{tabular}

Table 2. Sensitivity to lysis of cultures of Pseudomonas aeruginosa grown in the presence of different divalent cations and treated with polymyxin or EDTA

$\begin{array}{cccc}\text { Cation } & \begin{array}{c}\text { Concentration } \\ (\mu \mathrm{g} . / \mathrm{ml} .)\end{array} & \begin{array}{c}\text { Decrease in } E_{470} \begin{array}{c}\text { after I } 80 \mathrm{~min} . \\ \text { treatment with }\end{array} \\ \text { (I6 units } / \mathrm{ml} .)\end{array} & \begin{array}{c}\text { EDTA } \\ (375 \mu \mathrm{g} . / \mathrm{ml} .)\end{array} \\ \mathrm{Mg} & 0.05 & 0.01 \mathrm{I} & 0.005 \\ \mathrm{Mg} & \mathrm{I} .0 & 0.103 & 0.092 \\ \mathrm{Bg} & 0.37 & 0.01 \mathrm{I} & 0.009 \\ \mathrm{Ca} & 1.65 & 0.073 & 0.043 \\ \mathrm{Sr} & 3.60 & 0.064 & 0.005 \\ \mathrm{Ba} & 5.65 & 0.045 & 0.005 \\ \mathrm{Zn} & 2.69 & 0.040 & 0.024\end{array}$

Pseudomonas aeruginosa was grown with $0.05 \mu \mathrm{g} . \mathrm{Mg} / \mathrm{ml}$. and with other divalent cations in amounts which, on a molar basis, were equivalent to I $\mu \mathrm{g}$. Mg. $/ \mathrm{ml}$. Cultures were treated with polymyxin or EDTA as described above and the decrease in $E_{470}$ after $180 \mathrm{~min}$. contact with these agents determined. The data in Table 2 show that other divalent cations were able to replace $\mathrm{Mg}$ in varying degrees in its role concerned with sensitivity. The effects of the different cations varied according to the antibacterial agent used. 


\section{DISCUSSION}

The effects of polymyxin on Pseudomonas aeruginosa grown in $\mathrm{Mg}$ concentrations above $0.5 \mu \mathrm{g}$. $/ \mathrm{ml}$. correspond closely to findings of other workers. Newton (1953 $b$ ) observed that increasing the polymyxin concentration resulted in increased leakage from $P$. aeruginosa up to a maximum and any further increase in the polymyxin concentration gave decreased leakage. The initial increase in $E_{470}$ observed on treatment of $P$. aeruginosa grown in $\mathrm{I} \mu \mathrm{g} . \mathrm{Mg} / \mathrm{ml}$. with high polymyxin concentrations (Fig. I) is also paralleled by the finding of Hugo \& Longworth (1964). These authors reported that the $E_{500}$ of suspensions of Escherichia coli and Staphylococcus aureus increased after treatment with chlorhexidine and attributed the increase to a change in the light-scattering properties of the bacteria as a result of uptake of chlorhexidine. Not only did the activity of polymyxin in causing lysis, leakage and loss of viability of $P$. aeruginosa diminish as the $\mathrm{Mg}$ concentration in the growth medium was decreased to $0.05 \mu \mathrm{g} . / \mathrm{ml}$., but also no initial increase in $E_{470}$ occurred. Presumably there was little or no uptake of polymyxin by the pseudomonad. The patterns of lysis and leakage produced by polymyxin were very similar, both with regard to the effect of growth in different $\mathrm{Mg}$ concentrations and the inhibitory effect of high polymyxin concentrations. Also, the rates of lysis and leakage of a particular suspension were very similar, suggesting that these phenomena resulted from the action of polymyxin on a single site. There is evidence that polymyxin acts on the cytoplasmic membrane (Newton, 1955) and the observations of Warren, Gray \& Yurchenco (1957) that pretreatment of some Gram-negative bacteria with polymyxin rendered them sensitive to lysozyme, suggested that polymyxin, like EDTA, may also affect some relatively superficial component of the cell wall.

The decrease in colony count of suspensions of Pseudomonas aeruginosa treated with polymyxin (Fig. 9a) was greater than the change in $E_{470}$ or $E_{260}$. Therefore, the presence of another site of action of polymyxin seems possible particularly as Nakajima \& Kawamata (I966a, b, c) indicated that colistin affected the RNA of Escherichia coli. There is a similar possibility for EDTA in view of the observation of Neu, Ashman \& Price (1967) that EDTA affected RNA of E. coli.

Not only were lysis and leakage, caused by polymyxin (and EDTA), diminished by growing Pseudomonas aeruginosa in low Mg concentrations, but so too was the decrease in colony count. Loss of viability may possibly result from the effect of polymyxin on RNA; if this were so either the cell envelope altered when bacteria were grown in low $\mathrm{Mg}$ concentrations and no longer permitted these agents to enter the cell, or some alteration in the RNA occurred. The first possibility seems more probable for two reasons. Firstly, there was a definite indication that uptake of polymyxin by the bacteria was decreased as a result of growth in a low $\mathrm{Mg}$ concentration; there was a lack of initial increase in $E_{470}$ with high polymyxin concentrations. Secondly, changes in RNA seem less likely in view of the importance of its structure and biological function. Another possibility is that lethal membrane damage preceded lysis and leakage and occurred at a faster rate.

The increase in resistance of Pseudomonas aeruginosa which resulted from growth in low $\mathrm{Mg}$ concentrations was not associated with an alteration in growth rate in every case. Increasing the $\mathrm{Mg}$ concentration to values up to $0.5 \mu \mathrm{g}$. $/ \mathrm{ml}$. had a marked effect in increasing sensitivity to polymyxin (Fig. 2), but such a variation altered the 
growth rate only below about $0 . \mathrm{I} \mu \mathrm{g}$. Mg./ml. (Brown \& Melling, I969). It appears therefore that $\mathrm{Mg}$ is used preferentially for RNA synthesis; only when this requirement is satisfied is $\mathrm{Mg}$ available for other needs.

Newton (1954) proposed that antagonism of the action of polymyxin by $\mathrm{Mg}$ and other divalent cations resulted from competition between polymyxin and the cations for some negatively-charged site. He did not consider that a direct interaction of $\mathrm{Mg}$ and polymyxin was likely in view of the finding (Newton, 1953a) that 400 atoms of $\mathrm{Mg}$ were required to annul the antibacterial effect of one molecule of polymyxin. However, the striking similarity of the changes in resistance to polymyxin and to EDTA, produced in Pseudomonas aeruginosa by growth in low Mg concentrations suggest either a common site of action or at least a relationship between their sites of action. One explanation might be that $\mathrm{Mg}$ (or other cation) is required for synthesis of some sensitive component of the cell envelope and may itself be involved in the structure of this component. Thus, polymyxin might disrupt or be taken up by some negatively-charged site in the wall, while EDTA might chelate with the cation itself; in the absence of cations, sites for both inhibitors would be lacking. A polymyxinsensitive wall site might be phospholipid which has been identified in the wall of $P$. aeruginosa and is associated with cations (Gordon \& MacLeod, 1966; Clarke, Gray \& Reaveley, 1967; Bobo \& Eagon, I968). This hypothesis is consistent with the work of Few (1955) who showed that polymyxin E reacted with several lipids.

Cox \& Eagon (1968) reported that treatment of cell walls of Pseudomonas aeruginosa with EDTA caused solubilization of carbohydrates, divalent cations, some straightchain saturated fatty acids, a quantity of unidentified fatty acids and some phosphorus (but no phospholipid). These authors suggested that divalent cations may form crosslinkages via phosphate groups contained in the lipoprotein and lipopolysaccharide components of the cell wall. They suggested that both intra- and inter-molecular cross-linking may occur throughout those components. In the absence of divalent cations such cross-linking could not occur and perhaps, as in the case of Aerobacter aerogenes, deprivation of $\mathrm{Mg}$ results in a variation in the organic constituents of the cell wall (Ellwood \& Tempest, 1967). In such a case cross-linking by divalent cations might no longer be necessary for stability. Nevertheless it is especially interesting that these $\mathrm{Mg}$-limited $A$. aerogenes had an increase in the cell wall content of lipopolysaccharide.

Although $\mathrm{Mg}$ has been shown to be adsorbed by the surface of bacteria (Tempest \& Strange, I966) it has been shown in the present work that this is not sufficient to render Pseudomonas aeruginosa sensitive to EDTA or polymyxin. Cell division must occur in a high $\mathrm{Mg}$ concentration before bacteria grown in a low $\mathrm{Mg}$ concentration become sensitive to these agents (Table I). Since the mean generation time of P. aeruginosa under the particular growth conditions was about $90 \mathrm{~min}$., at least three divisions were needed before the sensitivity approached that of bacteria grown in a high $\mathrm{Mg}$ concentration throughout. It therefore seems reasonable to suggest that either incorporation of $\mathrm{Mg}$ into the cell wall or synthesis and incorporation of some component dependent upon $\mathrm{Mg}$ must occur to produce sensitive organisms.

Cations other than $\mathrm{Mg}$ varied in their effect on the sensitivity of Pseudomonas aeruginosa to EDTA or polymyxin (Table 2). The greatest increase in sensitivity to EDTA resulted from addition of $\mathrm{Ca}$. The effect of $\mathrm{Zn}$ was less, and $\mathrm{Be}, \mathrm{Sr}$ and $\mathrm{Ba}$ had no effect. With polymyxin, however, the order of effectiveness was $\mathrm{Ca}, \mathrm{Sr}, \mathrm{Ba}, \mathrm{Zn}$; 
beryllium had no effect. The order of chelation of these metals by EDTA, over the range $\mathrm{pH} 6 \cdot 5$ to $8 \cdot 5$ has been given as $\mathrm{Zn}>\mathrm{Ca}>\mathrm{Mg}>\mathrm{Sr}>\mathrm{Ba}$ (Welcher, $195^{8}$ ). Thus, two types of specificity appear to operate. First, there is the specificity of the organism for particular cations which would account for the fact that no other cation was as effective as $\mathrm{Mg}$ in producing sensitivity to EDTA and polymyxin. Secondly, there is the specificity of the inhibitor. The interaction of these two types of specificity may account for the fact that although $\mathrm{Zn}$ is most strongly chelated by EDTA, $\mathrm{Ca}$ and $\mathrm{Mg}$ were more effective in producing sensitive pseudomonads. The finding of Eagon et al. ( 1965$)$ that magnesium $(0.2 \%)$, calcium $(0.15 \%)$ and zinc $(0.09 \%)$ were constituents of the cell wall of $P$. aeruginosa may give a measure of the specificity of the cell wall for particular cations under the growth conditions used.

We are grateful to the Medical Research Council for a grant in support of this work.

\section{REFERENCES}

Boвo, R. A. \& EAgon, R. G. (1968). Lipids of cell walls of Pseudomonas aeruginosa and Brucella abortus. Can. J. Microbiol. 14, 503.

Brown, M. R. W., Farwell, J. \& Rosenbluth, S. A. (1969). Use of membrane filters for measurement of $260 \mathrm{~m} \mu$ absorbing substances from bacterial cells. Analyt. Biochem. 27, 484.

Brown, M. R. W. \& Melling, J. (1969). Loss of sensitivity to EDTA by Pseudomonas aeruginosa grown under conditions of Mg-limitation. J. gen. Microbiol. 54, 439.

Clarke, K., Gray, G. W. \& Reaveley, D. A. (1967). The extraction of cell walls of Pseudomonas aeruginosa with aqueous phenol: material from the phenol layer. Biochem. J. 105, 755 .

Cox, S. T. \& EAGON, R. G. (I968). Action of ethylenediaminetetraacetic acid, tris (hydroxymethyl)aminomethane and lysozyme on cell walls of Pseudomonas aeruginosa. Can.J. Microbiol. 14, 913.

Eagon, R. G., Simmons, G. P. \& CARSON, K. J. (I965). Evidence for the presence of ash and divalent metals in the cell wall of Pseudomonas aeruginosa. Can. J. Microbiol. II, I04I.

Ellwood, D. C. \& TEMPEST, D. W. (1967). Influence of growth condition on the cell wall content and wall composition of Aerobacter aerogenes. Biochem. J. 75, 253.

FEw, A. V. (1955). The interaction of polymyxin E with bacterial and other lipids. Biochim. biophys. Acta 16, I37.

Gordon, R. C. \& MACLEOD, R. A. (1966). $\mathrm{Mg}^{++}$phospholipids in cell envelopes of a marine and a terrestrial Pseudomonad. Biochem. biophys. Res. Commun. 24, 684.

HaAs, G. J. \& SevaG, M. G. (1953). Critical role of amino acids on the sensitivity and development of resistance to polymyxin B. Arch. Biochem. Biophys. 43, II.

Hugo, W. B. \& LONGWORTH, A. R. (1964). The mode of action of antibacterial agents. J. appl. Bact. 30, 17 .

Melling, J. (1968). The effect of growth medium on the resistance of Pseudomonas aeruginosa to chemical inactivation. Ph.D. Thesis, Bath University.

NaKajima, K. \& Kawamata, J. (1966a). Studies on the mechanism of action of colistin. III. Precipitation of Escherichia coli ribosomes with colistin. Biken.J. 9, 45.

Nakajima, K. \& Kawamata, J. (1966 $b$ ). Studies on the mechanism of action of colistin. IV. Activation of 'latent' ribonuclease in E. coli by colistin. Biken. J. 9, I 15 .

NaKaJima, K. \& KaWAMATA, J. (I966c). Studies on the mechanism of action of colistin. V. Action on the ribosomes. Biken. J. 9, 283.

Neu, H. C., Ashman, D. F. \& Price, T. D. (1967). Effect of ethylenediaminetetraacetic acid tris (hydroxymethyl) aminomethane on release of acid-soluble nucleotide pool and on breakdown of ribosomal ribonucleic acid in Escherichia coli. J. Bact. 93, 1360.

Newton, B. A. (1953a). Reversal of antibacterial activity of polymyxin by divalent cations. Nature, Lond. 172, 160 .

Newton, B. A. (1953b). The release of soluble constituents from washed cells of Pseudomonas aeruginosa by the action of polymyxin. J. gen. Microbiol. 9,54 . 
Newton, B. A. (1954). Site of action of polymyxin on Pseudomonas aeruginosa: antagonism by cations. J. gen. Microbiol. so, 491.

Newron, B. A. (1955). A fluorescent derivative of polymyxin: its preparation and use in studying the site of action of the antibiotic. J. gen. Microbiol. 12, 266.

Tempest, D. W. \& Strange, R. E. (I966). Variation in content and distribution of magnesium and its influence on survival in Aerobacter aerogenes grown in a chemostat. J. gen. Microbiol. 44, 273.

Warren, G. H., Gray, J. \& Yurchenco, J. A. (1967). Effect of polymyxin on lysis of Neisseria catarrhalis by lysozyme. J. Bact. 74, 788 .

WeLCHER, F. J. (1958). The Analytical Uses of EDTA. Princeton, New Jersey: D. van Nostrand Co., Inc. 